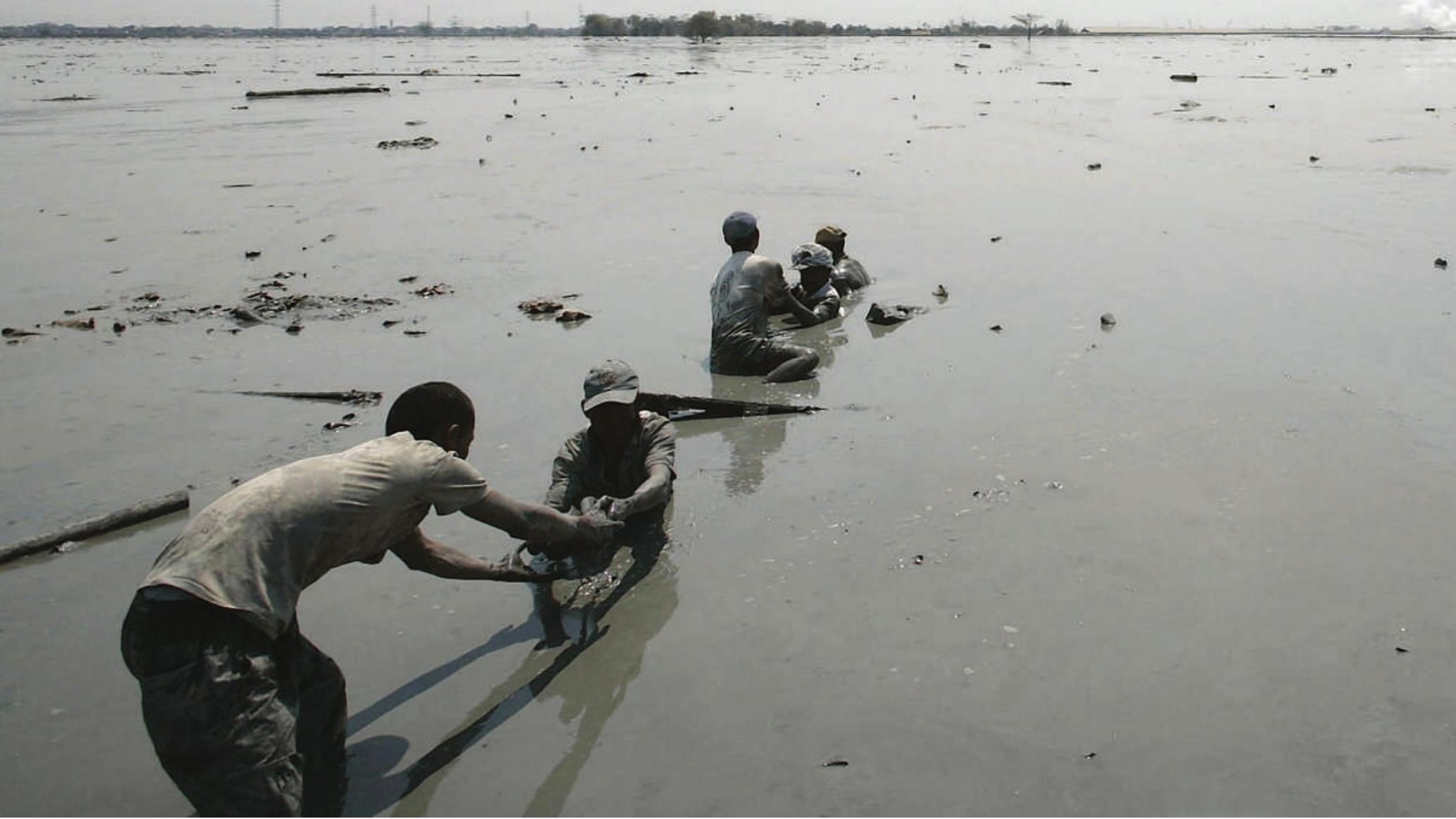

MUDDY WATERS

How did a mud volcano come to destroy an Indonesian town? David Cyranoski reports from Sidoarjo.

t started on 29 May 2006: a small spurt of mud in the middle of a rice paddy. Now the cauldron of hot, bubbling mud is some

50 metres in diameter and rises 16 metres above that long, submerged paddy. A dented horseshoe of a levee - the tallest of a series of often-failed efforts to protect homes and factories - tries to channel the muddy outflow towards a river. On the disaster-management maps that show those 13 kilometres of levee and 450 hectares of muddy devastation, the source at the centre is labelled simply 'Big Hole'.

The Big Hole, more commonly called Lusia contraction of lumpur for mud and Sidoarjo, the place in East Java where the mud is erupting, is the opening of what's called a mud volcano. It's not, perhaps, the most apt of names: the mud is more like thick water, and the volcano's only structure is that imposed on it by the artificial embankments. But if it gets across the idea of something bizarre and disastrous, then the name is doing its job. In the Big Hole, below the thick, billowing plumes of vapour, black waves ripple the unfathomable surface. "It's like the sea," says my guide - but a sea that is pockmarked with bubbles of gas from a source about which little is known, even after nine months.

A smooth black lake stretches for more than a kilometre in most directions, past treetops, past street lights, and over barely exposed roofs. The flow, which started at just 5,000 cubic metres a day, has now topped 130,000, and Lusi has already displaced 24,000 people. To the southwest, within an area closed off by levees, the mud has crusted over into chunky, grey blocks that come up to the eaves of a series of factories. In an earthwork-protected area that allows access to the Big Hole, bustling workers dismantle a drilling rig that tried and failed to intercept the mud surge on its way to the surface. On 22 November, the weight of the mud destroyed a gas pipeline, killing 13 disaster workers; two other workers have since died in accidents with heavy equipment.
And no one knows when the mud flood will stop: Richard Davies, a geologist at Durham University in the United Kingdom with an interest in mud volcanoes, points to some that have been spewing forth for months or even, as in the case of the Koturdag mud volcano in Azerbaijan, decades. "I expect Lusi to be bubbling for years to come," he says.

Lusi's devastation has so far been a defeat not only for civil engineering but also for scientific understanding. Efforts to figure out how it started have turned into a hotly contested whodunit with two suspects: a drilling project by an Indonesian oil-drilling company named PT Lapindo Brantas, and a nearby earthquake. Now Earth scientists are starting to weigh in. Geologist Adriano Mazzini at the University of Oslo in Norway sees it as a golden opportunity to learn about the evolution of these strange phenomena, which are generally studied only long after the structure has set. "We can see this one from day one," says Mazzini. But such 


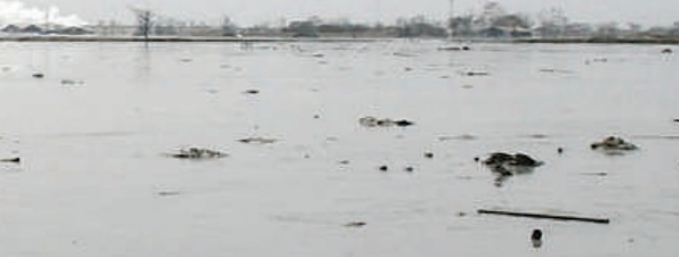

Production line: workers battle to save what they can from what used to be their homes and workplaces. to the promise of their name, with thick mud flowing from a raised, central crater. And many are genuinely, viscously muddy. "Some of them come out a couple of centimetres per day, like toothpaste," says Davies.

Lusi is exceptional in its sheer volume. It is also an outlier at the dilute, watery end of the volcanoes' viscosity spectrum. Its mud is about $70 \%$ water, according to Bambang Istadi, the exploration manager at PT Energi Mega Persada (EMP), Lapindo's parent company. After examining fossils within the mud, Istadi says that the particles in the mud come from a layer of shale and mudstone at a depth of somewhere between 1,220 and 1,830 metres. Davies says this mudstone continues down, mixed with sandbeds, to nearly three kilometres. Below that is the Kujung limestone formation, into which Lapindo was planning to drill in search of gas.

The first published analysis of the mud volcano, from a group led by Davies (R. J. Davies et al. GSA Today 17, 4-9; 2007), conjectures that the water driving the mud volcano comes from that Kujung limestone, and suggests that the escape could have been caused by Lapindo's drilling at a site called Banjar Panji1. The Banjar Panji-1 well is an exploratory well, started when little was known about the underlying geology. In his paper, Davies argues that the drill at Banjar Panji-1 punctured the Kujung, allowing high-pressure water and gas to escape into the borehole. The fluids forced their way into the surrounding rock and fractured it and the high-pressure water passing through these fractures liquefied the surrounding shale before new cracks gave it access to the surface. The cracks have been growing ever since.

As evidence, Davies cites abnormally high pressure readings for the Kujung formation taken some five kilometres away from Banjar Panji-1 and for a shallower layer right at the drilling site. Davies notes that he cannot say how he acquired these data, or present more data to back up his analysis because his source must be kept confidential.

Istadi, who oversaw the drilling of the well, describes Davies' paper as "preliminary conclusions, [with] interpretation based on an incomplete data set", and says that Davies did not contact his company to confirm the data. Istadi's main gripe is that drilling records show that the borehole never penetrated the Kujung formation. When the team hit an instability at 2,834 metres - around the depth that they had expected to find the Kujung - they too assumed that they had reached the limestone. "At first we thought so, but it can't possibly be," says Istadi. As evidence, he offers drilling cores that show no evidence of the 12-metre-thick layer of hardened clay that has been found draped over the Kujung elsewhere, and says that chloride levels in the water are twice as high as would be expected from the Kujung. Davies has since been contacted by Lapindo representatives who corrected a few details in his analysis, but says that nothing they told him changed his overall interpretation. He does, however, agree that the available evidence does not necessarily show that the drill entered the limestone.

\section{Shaken, not stirred}

Istadi offers another explanation for the volcano's origin. The day before the volcano erupted, a magnitude- 6.3 earthquake struck Yogyakarta, 280 kilometres to the southwest of Sidoarjo. Istadi says that seven hours after the earthquake, drilling fluid, which is circulated up and down the borehole to keep the pressure higher than that of the fluids in the surrounding rock, leaked out. He thinks this drilling loss, or 'loss of circulation', as it is known, was caused by shock waves from the earthquake - and that the same shocks might have triggered the mud volcano: "Faults became open, lost their sealing capacity, and became permeable." Those faults, he says, "served as the conduit where the mud flows out". This explanation squares well with the views of one of the country's most powerful and richest men, Aburizal Bakrie, the Coordinating Minister for People's Welfare. Bakrie, whose family owns part of Lapindo, has long been arguing that Lusi is just another "natural disaster" - no more the fault of an individual company than the earthquake itself, or the floods that have hit Jakarta in the past months.

But others have their doubts. Davies thinks that had the eruption, or the drilling loss, been triggered by the earthquake, it would have started much more promptly. Michael Manga, a geophysicist at the University of California, Berkeley, says a causal link between the earthquake and the mud volcano would be extremely surprising. Manga has collected data on the distances over which earthquakes have had similar impacts on Earth's plumbing, triggering mud volcanoes and other 'liquefaction events'. In 343 such events, Manga found a clear lower limit and the circumstances that start them off - like the Koturdag in Azerbaijan - live up 
below which earthquakes won't do the job (see graph). "If the Yogyakarta earthquake caused that mud volcano, it would have been way out of range," says Manga. Manga also found some recent earthquakes larger than 6.3 magnitude closer to the Big Hole that did not cause a mud volcano, suggesting that such weak seismic stress could not account for Lusi.

\section{A tragedy of errors}

Moreover, the drilling loss might have started a series of events that could implicate Lapindo further, suggests Andang Bachtiar, a consultant at Jakarta-based Exploration Think Tank Indonesia. The drill team reacted with a special drilling fluid to seal the fractures responsible for the loss of fluid. The next step was to pull the drill out and add cement to the unstable area at the bottom to secure it before they continued drilling. But at 8 a.m. on 28 May, when they were pulling the drill out, they got some 'kick' 1,293 metres down. Kick is basically the opposite of loss: instead of drilling fluids leaking out of the borehole, highly pressurized liquids or gas suddenly rush in. "The monster from below caught up with them," says Bachtiar.

An executive at EMP says that kick and loss are common, often anticipated and usually easily managed occurrences that have no connection with the rare disaster of the volcano. He did not wish to be named because he is currently under criminal investigation, along with a dozen other employees of EMP, Lapindo and subcontractors involved in the operation of the drilling project. "Kick and loss are like falling off a bike. It happens all the time. You just
SO NEAR, SO FAR

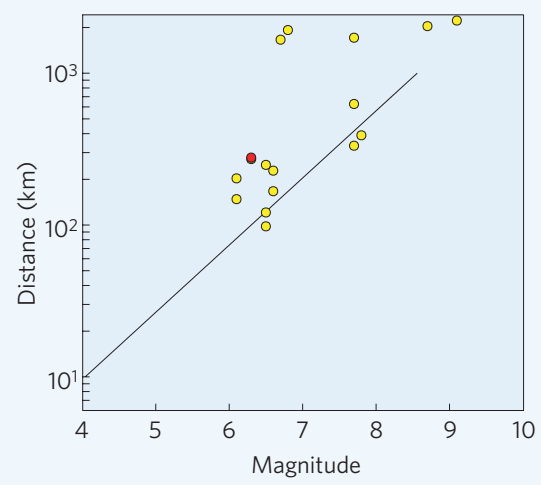

The likelihood that an earthquake will trigger events such as mud volcanoes depends on its magnitude and distance. The black line shows the cut-off above which no connection is expected. In the case of East Java, some of the recent earthquakes that have not caused mud volcanoes (yellow dots) are below the cut-off, and some have been closer to Sidoarjo and stronger than the Yogyakarta earthquake of May 2006 (red dot).

get back on. What you want to avoid is getting hit by a truck. That's what happened the next morning," he says.

But Davies and Bachtiar think the 'truck' came up through the borehole. "They drilled something overpressured, something that was driving the system," Davies says. Bachtiar, one of the first people to suggest that the drilling might have been connected with the mud volcano, was a witness in a police investigation into the possible link and thus studied Lapindo's drilling report closely. He suggests several ways in which what went on at the drilling site $\Sigma$ could have led to the eruption.

It is possible, he suggests, that the workers at the well withdrew their drill too quickly, losing control of the pressure in the hole. Istadi admits that they might have pulled out too fast, and that the effect could have been to suck in fluids from pressurized pockets in the rock, leading to the kick. But he insists that the kick was killed.

\section{Soft spots}

To 'kill' a kick, drillers circulate drilling fluid heavy enough to fight back the incoming liquid and gas. But this is a delicate process. The heavy fluid itself can open cracks in the surrounding rock, which the upcoming fluids can then enter. Lower strata are less vulnerable to cracking because the weight of overlying rock holds them together. In the shallower regions, steel casing is cemented to shore things up. The most vulnerable point is just below this casing - about a kilometre in the case of Banjar Panji-1. If the pressure caused by the heavy drilling fluid exceeds the pressure holding the rock together here, "it will be a disaster", says Bachtiar.

Rudi Rubiandini, a petroleum engineer at the Bandung Institute of Technology in Indonesia who led an investigation into the mud flow last June, believes that evidence in the drilling report shows that this is what happened. "It was very clear that the [rock] formation cracked," claims Rubiandini. The timing and the geographical location also suggest a connection between Lapindo's kick and the eruption.

\section{A unique plan to stem the flow}

Three Earth scientists at the Bandung Institute of Technology have hatched a plan to drop 1,000 chains, each with four concrete balls and weighing some 300 kilograms, into the neck of the mud volcano.

The aim is not to plug the hole, which could divert the pressure elsewhere, but to "tire" it out by making it work its way around the concrete balls. By restricting the size of the conduit, the team plans to cut the rate of flow (see Nature 445, 470; 2007). In the end, the same volume of mud will probably pump out, but at a lower rate. The innovators calculate that the rate of flow should fall by $75 \%$, giving them more time to reinforce embankments, channel the mud to the river and take other measures to spare the villages. "The balls will buy some breathing time," says Andang Bachtiar, an oil-exploration consultant at Jakarta-based Exploration Think Tank Indonesia.

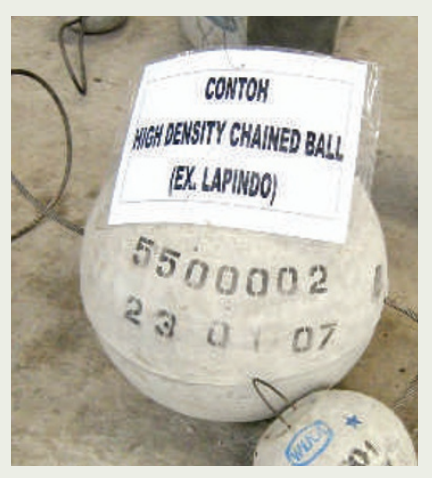

Scientists have generally given it mixed, and many-caveated, reviews. "It does seem to me that it is basically reasonable to assume that there is some pressure distribution that is causing flow, and that partially blocking the conduit will lower the flow rate," says Steve Tait, a vulcanologist at The Institute of Earth Physics in Paris, France.

But Tait adds: "One other outside possibility could be that if an outlet is blocked, the pressure distribution in the system creates a new conduit and point of emission."

Other scientists have noted, half in jest and half in fear, that putting concrete balls in the neck of a mud volcano could turn it into a cannon, shooting the balls straight back out.

Tait also points out that predictions about how the experiment will work depend on knowledge of where the mud is coming from and what path it is taking to get to the surface - things about which little is known.

Bagus Endar Nurhandoko, one of the project's creators, admits that the project could run into problems straight away if they misjudge the shape of the crater and shoot the balls to the wrong place. "The worst thing would be if the balls don't go down at all," he says. They are using sonar to try to figure this out before inserting the balls.

And as Satria Bijaksana - another of the Bandung trio - admits, many things that work on paper do not in reality. "This is real life. You can't take into account all the parameters." D.C. 
According to Istadi, the kick was resolved within four hours. Moreover, he claims that, at 2 p.m. on 29 May, long after Lusi had started, Lapindo did a test that showed that the borehole was not fractured, at least not at 1,091 metres, the weakest point. Below that, he says, the borehole would have been strong enough to withstand the force of the kick. Bachtiar says, however, that such tests are open to interpretation; other experts contacted by Nature also wondered how such a test could have worked.

Mark Tingay, a geologist at the University of Adelaide in Australia, says the Sidoarjo volcano has a striking similarity to drilling-induced eruptions offshore from Brunei in 1974 and 1979 (M. R. P. Tingay et al. J. Geol. Soc. 162, 39-49; 2005). There, deeply buried fluids under high pressure rose to a shallower rock formation that they then fractured, thus eventually reaching the surface. The event also showed the pattern of loss, kick and then eruptions seen in Lusi, some of which were kilometres from the drilling site. In the Brunei case, Shell, the company responsible for the drilling, has documented the expulsion and its efforts to alleviate the situation. The flow took more than 20 years and more than 20 relief wells to quell, says Tingay. "The similarities all suggest a man-made cause for Lusi," he says.

\section{Money matters}

Indonesia’s president, Susilo Bambang Yudhoyono, has already forced Lapindo to pay 3.8 trillion rupiah (US\$420 million) to help deal with the disaster, 2.5 trillion to provide relief and buy the despoiled land from its owners and 1.3 trillion to try to stem the flow. For Lapindo, the downside could get even worse if more villages flood or if it loses a lawsuit brought by Medco, Indonesia's largest oil producer and one of Lapindo's two partners in the joint venture responsible for the drilling.

Medco alleges that Lapindo should have put casing down to 2,591 metres to stabilize the hole, which might have made it possible to prevent or control any damage done by the kick. Some experts argue that the borehole should be cased for at least two-thirds of its depth and that Lapindo cut corners to save time and money. Lapindo, in a legal document sent to Medco on 2 February, countered the allegations by saying that the operating agreement requires Medco to cover its part of the liability. The letter ends: "Medco's ongoing failure to pay is jeopardizing the success of the Sidoarjo relief effort." The Australian company Santos, which holds 18\% of the joint venture and has several other drilling operations in Indonesia, had paid US\$15 million to the relief effort as of 8 December.

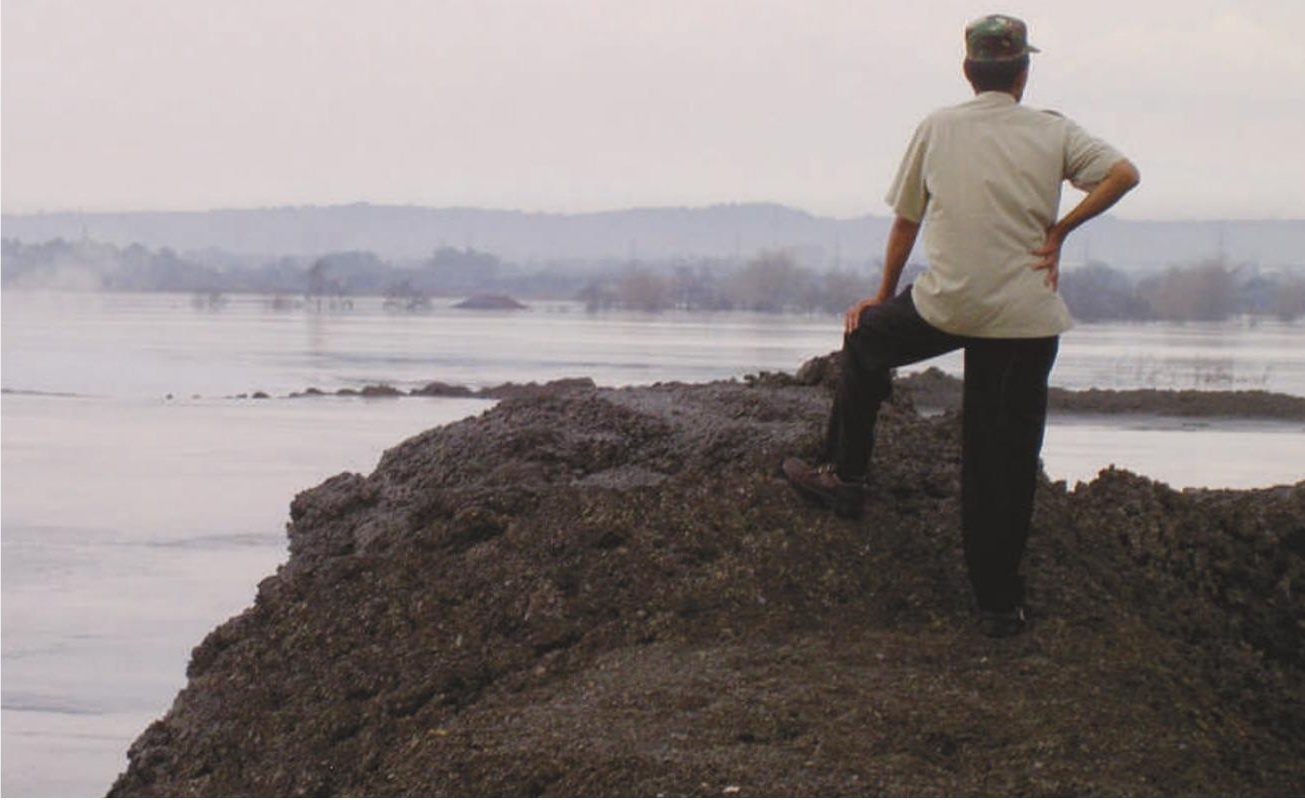

Wanderer above the sea of mud.

People in Indonesia have already made up their minds. If "mud volcano" is mentioned, they shoot back, "Ah, lumpur Lapindo" - the Lapindo mud. And the locals do not think "Lapindo relief" is coming fast enough, although the company says that it has already spent extensively on medical assistance, food, emergency and temporary housing and cash allowances for the people of the villages.

Despite the damage, the area has become a spectacle as well as a wasteland. Locals have become self-designated toll masters trying to recoup from visitors what the Big Hole took from them. Making left turns, right turns and U-turns on the roads costs 1,000 rupiah (about 10 cents), as do roadside parking spots that had previously been mere dusty lots. Some bare-chested musicians on the side of one highway, who call themselves 'Victims of the Hot Mud', play guitar and dance to drums.

A motorcycle guide at the site is happy to take me along one of the earthworks. At one
eels down and tosses a rock some point, he kneels down and tosses a rock some
20 metres. It plops. "That is where my house is," he says. Looking in the opposite direction from the same embankment, he points to a partially submerged factory where he used to make plastic and rattan. Lapindo, as part of a government order, has agreed to buy the land and property affected - but it is not clear when any payment will be made. In the meantime, my guide makes a living by guiding tourists to see the destruction that waylaid his home and job and selling them CD-ROMS of photography - although mine didn't work. As a motorcycle guide he makes 30,000 rupiah a day, compared with 700,000 rupiah a month in the old days. "Not bad," I say. "I have no house," he reminds me.

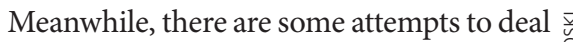
with the problem at the source. Rubiandini says that last year he and his team planned a series of $\frac{\infty}{\partial}$ relief wells to intercept the conduit bringing the mud up and staunch the flow by sending heavy mud back down. Two wells were started; both failed before reaching a third of the required 2,500-2,800 metres. "The drilling teams were constantly off and on because the money wasn't there. People are not serious about killing this," he says, apparently referring to Lapindo. Istadi retorts, "We gave him $\$ 80$ million. We gave him everything. Even if he had had more time it would not have worked. Anyway, the whole project assumes that the borehole is to blame. And we don't know that."

\section{Energy zapper}

The government has also undertaken a project to push the mud out into a nearby river, so far with little success. The latest hopes rest on an untested scheme to drop concrete balls down the Big Hole to soak up the energy of the upcoming flow (see 'A unique plan to stem the flow'). But for now, it seems that the mud will continue to flow, and the ground will continue to sink under its weight. The hopes for the 200,000 houses under threat depend on the effective use of levees. Basuki says they have already brought in 2.5 million cubic metres of dirt. "We moved a mountain," he says. But more science is needed too, since things might not merely continue, but get worse. For example, says Davies, the central vent could collapse as more and more mud gets removed from the subsurface and spreads its burden over the land. Other mud volcanoes have sunk 500 metres at the centre and forced land to sag for five kilometres around. The Big Hole could yet get bigger still.

David Cyranoski is Nature's Asia-Pacific correspondent. 